(International Journal of Agriculture and Wild life Science)
http://dergipark.org.tr/ijaws

Araştırma Makalesi

\title{
Böğürtlen (Rubus fructicosus L.) Odun Çeliklerinde Çelik Çapı ve İndol Butirik Asit (IBA) Dozlarının Köklenmeye Etkisi
}

\author{
Hamdi Zenginbal ${ }^{1 *}$, Muttalip Gündoğdu ${ }^{2}$ \\ ${ }^{1}$ Bolu Abant İzzet Baysal Üniversitesi, Bolu Teknik Bilimler Meslek Yüksekokulu, Park ve Bahçe Bitkileri Bölümü, Bolu \\ ${ }^{2}$ Bolu Abant İzzet Baysal Üniversitesi, Ziraat Fakültesi, Bahçe Bitkileri Bölümü, Bolu \\ Geliş tarihi (Received): 24.07.2020 Kabul tarihi (Accepted): 03.09.2020
}

\begin{abstract}
Anahtar kelimeler:
Böğürtlen, odun çeliği, çelik çapı, IBA

*Sorumlu yazar

hzenginbal@gmail.com

Özet. Bu çalışmanın amacı, farklı çelik çapı ve indol butirik asit (IBA) dozunun 'Chester' böğürtlen (Rubus fructicosus L.) çeşidi odun çeliklerinin köklenmesi üzerine etkisini belirlemektir. Köklenme için odun çelikleri Sakarya ili Geyve ilçesinden 25 Şubat 2018 tarihinde sağlıklı bitkilerden (bir yıllık sürgünler) alındı. Çelikler aynı uzunlukta olacak şekilde $(20 \mathrm{~cm}) 3$ farklı çapta $(4-6 \mathrm{~mm}, 7-11 \mathrm{~mm}$ ve 12-16 mm) hazırlandı. Daha sonra çeliklerin dip kısmı $(1 \mathrm{~cm}), 10$ saniye süreyle 0, 500, 1000, 1500 ve 2000 ppm IBA içeren sıvı çözeltiye (\%50 etanol + \%50 damııılmış su) daldııılı ve havada kurumaya bırakıldı. IBA uygulamasından sonra çelikler, ısıtmasız serada perlit ortamında 75 gün boyunca köklenmeye alındı. Çalışmada köklenme ve canlılık oranı, kök sayısı ve uzunluğu değerlendirildi. Araştırma sonucunda, canlılık oranı \%30.0 ile \%98.0 arasında, köklenme oranı \%10.0 ile \%80.0 arasında, kök sayısı 3.0 ile 23.2 arasında, kök uzunluğu ise $4 \mathrm{~cm}$ ile $15.4 \mathrm{~cm}$ arasında değişim göstermiştir. Bütün parametrelerde en yüksek sonuçlar 1000 ppm IBA uygulaması yapılan 7-11 mm çapındaki çeliklerden alınmıştır. Sonuçlar, 7-11 mm çapında hazırlanarak 1000 ppm IBA uygulaması yapılan çeliklerde kontrol ve diğer IBA uygulaması ve çelik çaplarına kıyasla köklenme oranı ve kök kalitesini arttırdığı ve oldukça etkili olduğunu göstermiştir.
\end{abstract}

\section{Effect of Cutting Diameter and Indole-3-Butric Acid (IBA) Doses on Rooting of Blackberry (Rubus fructicosus L.) Hardwood Cuttings}

\section{Keywords:}

Blackberry, hardwood cuttings, cutting diamater, IBA

\begin{abstract}
The objectives of this study were to determine the effect of different cutting diameter, and indole-3-butyric acid (IBA) doses on rooting of blackberry (Rubus fructicosus L.) cultivar 'Chester' hardwood cuttings. The hardwood stem cuttings (one-year-old shoots) for rooting were selected from healthy plants on February 25, 2018 in Geyve, Sakarya. Cuttings were prepared as three different diameters $(4-6 \mathrm{~mm}, 7-11 \mathrm{~mm}$, and $12-16 \mathrm{~mm})$ in a fixed length $(20 \mathrm{~cm})$. And then the basal portion of cuttings $(1 \mathrm{~cm}$ ) was dipped in liquid solution of either $0,500,1000,1500$, and 2000 ppm IBA ( $50 \%$ ethanol $+50 \%$ distilled water) for 10 second and allowed to air dry. After pretreating with IBA, the cuttings were rooted for 75 days in unheated greenhouse containing perlite medium. The rooting and viability rates, root number, and root length were evaluated in study. As a result of the study, the viability rate varied from 30.0 to $98.0 \%$, the rooting rate varied from 10.0 to $80.0 \%$, the number of root varied from 3.0 to 23.20 , the root length varied from 4.0 to $15.4 \mathrm{~cm}$. The highest results in all parameters were obtained from hardwood cutting prepared with 7-11 $\mathrm{mm}$ cutting diameter treated with 1000 ppm IBA. The results indicated that 7-11 cutting diameter treatment with $1000 \mathrm{ppm}$ IBA solution was highly effective in increasing rooting rate and quality when compared to control, and all other IBA treatments and cutting diameters.
\end{abstract}




\section{GiRiş}

Ülkemizin hemen hemen her bölgesi doğal ortamında böğürtlenin yabani formlarına rastlamak mümkündür. Böğürtlen, sofralık taze tüketiminin yanında meyve suyu, reçel, marmelat, konserve, pasta, jöle (içerdiği pektin 'den dolayı), dondurma ve içki yapımında kullanılmaktadır. Çok çeşitli değerlendirme şekli olmasından dolayı böğürtlen tarıma dayalı sanayi kuruluşları için ekonomik öneme sahip bir meyve türüdür (Ağaoğlu, 1986; Göktaş, 2011).

Kuzey Amerika'da Rubus türlerinden çok farklı özelliklere sahip (dikenli, dikensiz, dik, yarı dik ve yerde sürünen) ticari böğürtlen çeşitleri (Rubus sp. L.) geliştirilmiştir (Bobrowski ve ark., 1996; Poling, 1996). Dünyada ve Türkiye'de başlıca 'Black Satin', 'Dirkson Thornless', 'Arapaho', 'Cheroke', 'Theodor Reimers', 'Boysenberry', 'Chester', 'Nessy', 'Darow', 'Lawton', 'Navaho', 'Bursa-I', 'Bursa-II' ve 'Bursa-III' böğürtlen çeşitleri yetiştirilmektedir (Barut, 2004). ABD'de yetiştiriciliği çok yaygın olan 'Chester' böğürtlen çeşidi, yarı dik ve orta kuvvette gelişen dikensiz bir çeşittir. Düşük sıcaklık ve hastalıklara dayanıklı olmasından dolayı değişik ekolojilere çok iyi adapte olabilme özelliği taşımaktadır. Meyveleri orta irilik ve sertlikte olup parlak siyah renkli ve yuvarlaktır. Tam olgunlaşmadan önce meyveler biraz asitli olup tam olgunlaştığında mükemmel aromaya sahiptir. Tanelenme özelliği orta seviye olan çeşidin sürgün başına verimi 200 gramdır (Poling, 1986; Barut, 2004).

Türkiye'de resmi istatistiklere 2012 yılında yansıyan böğürtlen verileri, üretim miktarı açısından Türkiye üzümsü meyve üretiminde çilek ve ahududundan sonra 2708 ton 'la üçüncü sırada yer almaktadır. Türkiye böğürtlen üretiminin \%78'ini (2113 ton) Bursa ili karşılamaktadır (TÜiK, 2019). Sofralık tüketimin yanında sanayide değerlendirme şeklinin çok olması nedeniyle ülkemizde böğürtlen yetiştiriciliğine talep gün geçtikçe artmaktadır. Artan talebin karşılanabilmesi için her şeyden önce piyasada tutulan ve rağbet gören kaliteli böğürtlen fidanlarının yeterli sayıda üretilmesi gerekmektedir. Caldwell (1984) ve Göktaş (2011) bildirimlerine göre böğürtlen fidan üretimi generatif (tohumla) ve vegetatif yollarla yapılmakta ise de yaygın olarak daldırma (uç daldırma), kök sürgünleri, gövde çeliği (odun, yeşil ve yarı odun), yaprak-göz çeliği, kök çeliği ve doku kültürü gibi vegetatif yolla yapılmaktadır.

Her bir çoğaltma yöntemin avantaj ve dezavantajları vardır. Daldırmayla çoğaltma (uç daldırma) basit bir yöntem olmasına karşın özellikle sürgünleri dik büyüyen çeşitlerde uygulanması zor olmakla birlikte sürgünleri yatırmak, köklenme ortamı hazırlanmak ve yabancı otla mücadele yapmak için yoğun iş gücü gerektirmektedir. Bunun yanında fidan üretim katsayısı oldukça düşüktür. Yaprak-göz çeliği ile fidan üretimi başarılı bir şekilde uygulanmaktadır. Fakat yaprak-göz çeliğinin sürgün üzerindeki konumu köklenmeyi etkilemekte ve çoğaltma katsayısı düşük olduğundan dolayı yaygın olarak kullanılmamaktadır (Caldwell, 1984; Hartmann ve ark., 2011; Takeda ve ark., 2011). Doku kültürü yöntemi, yüksek teknoloji gerektirdiğinden dolayı tesisi için yatırım masrafı oldukça yüksektir. Bu nedenle büyük ticari fidan üreticileri bu yöntemi kullanmaktadırlar. Ancak küçük ölçekli fidan üreticileri yatıım masrafı en az olan üretim tekniklerini seçmektedirler. Bunun için damızlık bitkilerden alınan odun, yeşil ve yarı odun çelikleriyle fidan üretimi yapmaktadırlar (Lopez-Medina ve Moore, 1997; Bray ve ark., 2003; Takeda ve ark., 2011).

Uygulanması basit ve üretim maliyeti düşük olması sebebiyle çelikle çoğaltma çok sayda fidan üretimi için tercih edilmektedir (Takeda ve ark., 2011). Dik büyüme özelliği gösteren bazı böğürtlen çeşitleri yeşil, yarı odun ve kök çelikleriyle başarılı bir şekilde çoğaltılabilmektedir (Zimmerman ve ark., 1980; Busby ve Himelrick, 1999; Thompson, 2004). Yeşil ve yarı odun çeliklerin köklendirilmesi için köklendirme ortamında mistleme ünitesinin olması ve birkaç hafta boyunca mistleme yapılması gerekmektedir (Busby ve Himelrick, 1999; Takeda ve ark., 2011). Nitekim bazı dikenli böğürtlen çeliklerinin plastik örtü altında, sisleme ünitesine sahip olmayan ortamlarda köklenmesi aralıklı sisleme ünitesine sahip ortamlardaki kadar iyi olmadığı belirtilmiştir (Zimmerman ve ark., 1980). Bunun yanında böğürtlenin odun çelikleri mistleme olmaksızın çoğaltılabileceği bildirilmiş ancak çeşide bağlı olarak köklenme başarısının düşük (<\%50 köklenme) ve değişken olduğu belirtilmiştir (Zimmerman ve ark., 1980; Lopez-Medina ve Moore, 1997; Busby ve Himelrick, 1999; Bray ve ark., 2003).

Odun çelikleri ticari ve amatör fidan üretiminde yaygın olarak kullanılmamakla birlikte kış budaması sonrasında bitkisel atıkların değerlendirilmesi açısından önemli görülmektedir. Bu çoğaltma tekniği sayesinde işe yaramaz budama atıkları değerlendirilerek bitki başına çok sayıda fidan üretimi yapılmakta ve üreticiler için fidan maliyeti azalmaktadır. Azalan maliyete ek olarak yetiştiriciler için virüs bulaşmasına olası bir çözüm olarak görülmektedir. Yetiştiricilerin klonal üretimde virüs testi yapılmış virüssüz damızlık bitkilerden alınan çelikler sayesinde virüssüz fidan üretimi yapıldığı belirtilmektedir (Ahrens, 1991; Thompson, 2004).

Odun, yeşil ve yarı odun böğürtlen çelikleri köklendirme hormonu (oksin) uygulanmadan köklenmesine karşın Rubus sp. çeliklerinin kök sistemi geliştirmesi için oksin uygulanmasının köklenmeyi arttırdığı belirtilmektedir (Williams ve Norton, 1959; Busby ve Himelrick, 1999). Böğürtlen çeliklerine oksin grubu 
büyümeyi düzenleyici maddelerden olan indol butirik asit (IBA) uygulaması ile değişik sonuçlar alınmıştır (Zimmerman ve ark., 1980; Lopez-Medina ve Moore, 1997; Busby ve Himelrick, 1999; Bray ve ark., 2003). LopezMedina ve Moore (1997), \%0.3 IBA uygulaması ile dik büyüyen 'Arkansas' böğürtlen çeşidine ait odun çeliklerinde kök hacmi geliştiğini belirtmiş̧ir. Busby ve Himelrick (1999), 4 farklı böğürtlen çeşidine ait yarı odun çeliklerde yapmış oldukları çalışmada, Temmuz ayında çelikleri (2 boğumlu) alarak sıvı ve toz halindeki IBA uygulaması (\%0.1, 0.3 ve 0.8) yaptıktan sonra mistleme ünitesine sahip seraya dikmişlerdir. Araştırma sonucunda, çeliklerde kök gelişimini 0.3 ve \%0.8 sıvı IBA hızlı daldırma yöntemi uygulanan 'Navaho' çeşidinde kontrol uygulamasına göre çok daha yüksek bulmuşlardır. Kök kalitesi ise $\% 0.1$ ve $\% 0.8$ toz IBA ve $\% 0.3$ ve $\% 0.8$ SıVı IBA hızlı daldırma uygulaması yapılan dikensiz 'Chester' çeşidinde kontrol çeliklerine göre daha iyi gelişme gösterdiğini belirlemişlerdir. Bir diğer çalışmada ise Bray ve ark. (2003), 'Apache', 'Arapaho', ve 'Navaho' böğürtlen çeşitlerine ait odun çeliklerini bir yıllık sürgünlerin uç, orta ve dip kısmından şubat ayında alarak perlit ortamında, cam serada köklenmeye almışlardır. Çeliklere 0 ve 3000 ppm IBA uygulamışlardır. Çalışma sonucunda sürgünlerin dip kısmından alınan ve 3000 ppm IBA uygulaması yapılan çeliklerden en yüksek, uç kısmından alınan ve 0 ppm IBA uygulaması yapılan çeliklerden ise en düşük sonuçlar almışlardır.

Bu çalışmada, böğürtlenlerin odun çelikleriyle çoğaltılması araştırılmıştır. Genel amacımız 'Chester' böğürtlen çeşidinin ticari fidan üretimi için basit ve verimli çoğaltım tekniği belirlemektir. Özel hedefimiz ise IBA (indol butirik asit) dozlarının ve çelik çapının köklenme üzerine etkilerini belirlemektir.

\section{MATERYAL VE METOT}

Bu araştırma, 2018 yıllında Bolu Abant İzzet Baysal Üniversitesi Bolu Teknik Bilimler Meslek Yüksekokulu'na ait antifog ve UV katkılı plastik örtüye sahip, ısıtma ünitesi olmayan yüksek tünelde yapılmıştır.

Araştırma süresince (1 Mart - 15 Mayıs) plastik örtüye sahip yüksek tünelde sıcaklık $\left({ }^{\circ} \mathrm{C}\right)$ ve oransal nem (\%) verileri 30 dakika aralıklarla elektronik sıcaklık ve nem kaydediciyle (HOBO U10 Temp/RH) alınmış ve günlük ortalamalar hesaplanmıştır.

Araştırmada, bitkisel materyal olarak 'Chester' böğürtlen çeşidi kullanılmıştır. Çelikler, Sakarya ili Geyve ilçesi üretici bahçesinden 25 Şubat tarihinde alınmış ve ortalama $20 \mathrm{~cm}$ uzunluğunda hazırlanmıştır. Çeliklerin üst kısmı üst gözün hemen üzerinden çeliklerin dip kısımları ise alt gözün $1 \mathrm{~cm}$ altından düz bir şekilde kesilmiş ve akabinde 1-1.5 cm uzunluğunda kabuk dokusu odun kısmına kadar çizilerek yara dokusu oluşturulmuştur. Daha sonra çelikler, fungusit (Benlate \%0.3'lük) çözeltisi içinde 10 dakika tutularak mantar enfeksiyonlarına karşı dezenfekte edilmiştir. Araştırmada 4-6 mm, 7-11 mm ve 12-16 mm olmak üzere 3 farklı çelik çapı; 0 (kontrol), 500, 1000, 1500 ve 2000 ppm olmak üzere 5 farklı IBA dozu denenmiştir. Çözeltiler etkili madde (IBA) $50 \mathrm{~mL}$ etil alkolde eritildikten sonra $50 \mathrm{~mL}$ saf su eklenerek çözelti $100 \mathrm{~mL}$ 'ye tamamlanarak hazırlanmıştır. Kontrol çözeltisi olarak ise \%50 etil alkol ve \%50 saf sudan oluşan 100 mL'lik çözelti kullanılmıştır. IBA çözeltisine çeliklerin 1-1.5 cm'lik dip kısımları 10 saniye süre ile (hızlı daldırma yöntemi) muamele edilerek yüksek tünelde, siyah polietilen poşetler içerisine doldurulmuş perlit ortamında, 1 Mart tarihinde köklenmeye alınmıştır. Çelikler 75 gün sonra yani 15 Mayıs tarihinde köklendirme ortamından sökülerek canlıık ve köklenme oranı (\%), kök sayısı (adet) ve uzunluğu $(\mathrm{cm})$ belirlenmiştir.

Çalışma, üç tekerrürlü ve her tekerrürde 50 çelik olacak şekilde tesadüf parselleri deneme desenine göre planlanmıştır. Veriler JMP 13 paket programında istatistiksel analize tabi tutulmuş ve farklılıkları belirlemek için Duncan çoklu karşılaştırma testi kullanılmıştır. IBA dozları ile çeliklerin köklenme ile ilgili parametreleri arasındaki korelasyonu belirlemek için temel bileşen analizinde (PCA) biplot grafiği R (Comprehensive R Archive Network, 2020) programı kullanılarak çizilmiştir.

\section{BULGULAR VE TARTIŞMA}

Deneme süresince (1 Mart ile 15 Mayıs tarihleri) plastik örtülü yüksek tünelde günlük ortalama sıcaklık ve oransal nem değerleri hesaplanmış ve günlük ortalama veriler "Şekil 1"de sunulmuştur. Örtü altı yüksek tünelde günlük ortalama sıcaklık değerleri $5.4^{\circ} \mathrm{C}$ ile $23.5^{\circ} \mathrm{C}$ arasında, oransal nem değerleri ise \%40.5 ile \%95.8 arasında değişim göstermiştir. Genel olarak 1 Mart tarihinden 15 Mayıs tarihine doğru hava sıcaklığında artış, oransal nem değerlerinde ise dalgalanma görülmüştür. Deneme süresince yani 75 günlük ortalama sıcaklık $16.09{ }^{\circ} \mathrm{C}$, oransal nem ise \% 64.70 olarak gerçekleşmiştir. Hartmann ve ark. (2011), çeliklerin köklenmesi için ideal hava sıcaklığının gündüz $70{ }^{\circ} \mathrm{F}\left(\approx 21.11{ }^{\circ} \mathrm{C}\right)$, gece ise $60^{\circ} \mathrm{F}\left(\approx 18.33^{\circ} \mathrm{C}\right)$; köklendirme ortamının sıcaklığının $70^{\circ} \mathrm{F}$ $\left(\approx 21.11^{\circ} \mathrm{C}\right)$ ile $75^{\circ} \mathrm{F}\left(\approx 23.89^{\circ} \mathrm{C}\right)$ olması gerektiğini ve tropik bitkilerde bu değerin $10^{\circ} \mathrm{F}\left(\approx 12.22{ }^{\circ} \mathrm{C}\right)^{\prime} \tan$ daha fazla olması gerektiğini belirtmektedirler. Bunun yanında araştıııılar oransal nemin odun çelikler için en az \% 55 
olması gerektiğini belirtmektedirler. Bu bildirimler neticesinde araştırma ortamı hava sıcaklık ve oransal nem değerlerinin çelik köklenmesi için uygun değerlere yakın olduğunu bize göstermektedir.

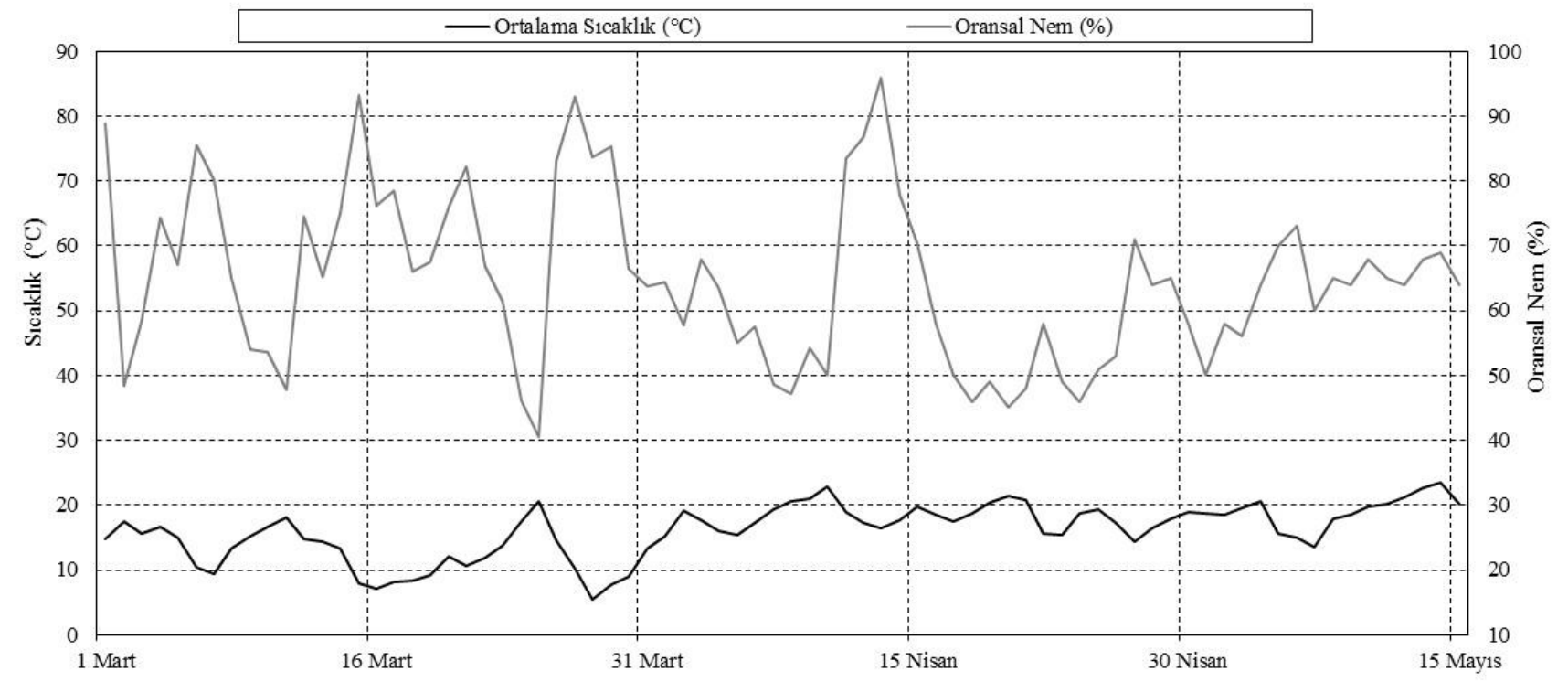

Şekil 1. Araştırma süresince günlük ortalama sıcaklık $\left({ }^{\circ} \mathrm{C}\right)$ ve oransal nem (\%) değerleri.

Figure 1. The daily mean temperature $\left({ }^{\circ} \mathrm{C}\right)$ and relative humidity $(\%)$ values during the course of investigation.

'Chester' böğürtlen çeşidi odun çeliklerinin köklenmesi üzerine çelik çapı ve IBA dozlarının etkilerine ait sonuçlar Çizelge 1'de verilmiştir. Canlılık ve köklenme oranı (\%) üzerine IBA x çelik tipi etkileşiminin çok önemli etkileri olmuştur (Çizelge 1). En yüksek canlıık oranı (\% 98.0) 500 ppm uygulaması yapılan 7-11 mm çapındaki çeliklerden alınmıştır. Köklenme oranı bakımından en yüksek sonuç (\%80.0) ise 1000 ppm IBA uygulaması yapılan 7-11 mm çapındaki çeliklerden alınmıştır. Çelik tipinin canlılık oranı üzerine etkisine bakıldığında 4-6 mm ve 12-16 mm çapındaki çeliklerin IBA ile interaksiyonunda istatistiksel olarak önemli bir fark görülmemiştir. Fakat 7-11 mm çapındaki çeliklerde IBA dozunun etkisi istatistiksel olarak $p<0.01$ düzeyinde önemli bulunmuştur. Yapılan araştırmada, köklenme oranı parametreleri incelendiğinde çelik çaplarının farklı hormon düzeyleri ile ilişkisinin istatistiksel olarak önemsiz olduğu belirlenmiştir. Kök sayısı, 4-6 mm çaplarına sahip çeliklerde artan IBA dozlarının etkisi istatistiksel olarak $p<0.01$ düzeyinde önemli olduğu tespit edilmiştir. Kök uzunluğu değerlerine bakıldığında ise $7-11 \mathrm{~mm}$ ve $12-16 \mathrm{~mm}$ çaplarındaki çeliklerin artan IBA dozlarına göstermiş olduğu reaksiyonun etkisi istatistiksel olarak $p<0.01$ düzeyinde önemli bulunmuştur.

Çizelge 1. Farklı çelik çapı x IBA dozlarının böğürtlen odun çeliklerinin köklenmesi üzerine etkileri.

Table 1. Interactive effect of IBA concentration and cutting diameter on rooting of hardwood cuttings of blackberry.

\begin{tabular}{|c|c|c|c|c|c|c|c|}
\hline \multirow{2}{*}{ Kriterlere } & \multirow{2}{*}{$\begin{array}{l}\text { Çelik Çapı } \\
(\mathbf{m m})\end{array}$} & \multicolumn{5}{|c|}{ IBA (ppm) } & \multirow{2}{*}{ P değeri } \\
\hline & & Kontrol & 500 & 1000 & 1500 & 2000 & \\
\hline \multirow{3}{*}{ Canlılık Oranı (\%) } & $4-6$ öd & $60.00 c^{s}$ & $78.00 \mathrm{~b}$ & $88.00 \mathrm{ab}$ & $68.00 \mathrm{~b}$ & $58.00 \mathrm{a}$ & 0.4320 \\
\hline & $7-11^{*}$ & $94.00 \mathrm{a}$ & $98.00 \mathrm{a}$ & $96.00 \mathrm{a}$ & $88.00 \mathrm{a}$ & $54.00 \mathrm{a}$ & 0.0241 \\
\hline & $12-16^{\text {öd }}$ & $72.00 \mathrm{~b}$ & $72.00 \mathrm{~b}$ & $78.00 \mathrm{~b}$ & $72.00 \mathrm{~b}$ & $30.00 \mathrm{~b}$ & 0.3002 \\
\hline \multirow{3}{*}{ Köklenme Oranı (\%) } & $4-6$ öd & $10.00^{\text {ÖD }}$ & 52.00 ÖD & $72.00 \mathrm{a}$ & $36.00 \mathrm{~b}$ & $36.00 \mathrm{a}$ & 0.6059 \\
\hline & $7-11^{\text {öd }}$ & 14.00 & 48.00 & $80.00 \mathrm{a}$ & $62.00 \mathrm{a}$ & $18.00 \mathrm{~b}$ & 0.0884 \\
\hline & $12-16^{\text {öd }}$ & 14.00 & 46.00 & $48.00 \mathrm{~b}$ & $34.00 \mathrm{~b}$ & $18.00 \mathrm{~b}$ & 0.8075 \\
\hline \multirow{3}{*}{ Kök Sayısı (adet) } & $4-6^{\star \star}$ & 3.00 ÖD & 9.60 ÖD & $18.20 \mathrm{ab}$ & 13.20 ÖD & $12.20 \mathrm{a}$ & 0.0069 \\
\hline & $7-11^{\text {öd }}$ & 4.00 & 14.00 & $23.20 \mathrm{a}$ & 15.40 & $13.20 \mathrm{a}$ & 0.0588 \\
\hline & $12-16^{\text {öd }}$ & 4.00 & 10.60 & $15.40 \mathrm{~b}$ & 12.20 & $8.60 \mathrm{~b}$ & 0.3785 \\
\hline \multirow{3}{*}{ Kök Uzunluğu (cm) } & $4-6$ öd & 4.00 ÖD & 10.20 ÖD & $14.70^{O ̈ D}$ & 12.20 ÖD & $11.20^{\text {ÖD }}$ & 0.0992 \\
\hline & $7-11^{\star *}$ & $6.00 \mathrm{~d}$ & $10.40 \mathrm{c}$ & $13.40 \mathrm{ab}$ & $15.40 \mathrm{a}$ & $13.00 \mathrm{~b}$ & 0.0055 \\
\hline & $12-16^{* *}$ & $6.00 \mathrm{~d}$ & $9.20 \mathrm{c}$ & $12.20 \mathrm{~b}$ & $13.00 \mathrm{a}$ & $12.00 \mathrm{~b}$ & 0.0039 \\
\hline
\end{tabular}

* Aynı satırda yer alan değerler üzerine IBA dozunun etkisi $p<0.05$ düzeyinde önemlidir.

**Aynı satırda yer alan değerler üzerine IBA dozunun etkisi $p<0.01$ düzeyinde önemlidir.

öd: Aynı satır içerisinde yer alan değerler üzerine IBA dozunun etkisi istatistiki olarak önemsizdir.

s: Aynı sütünda farklı harfler alan değerler istatistiki olarak farklıdır.

ÖD: aynı sütunda yer alan değerler arasında istatistiki fark yoktur. 
Yapılan araştırmada böğürtlen çeliklerinin canlılık oranı, köklenme oranı, kök sayısı, kök uzunluğu ile artan IBA dozları arasındaki varyasyonun \%98.2 olduğu tespit edilmiştir (Şekil 2). Temel bileşen analizi sonucunda sadece iki bileşenin bu oranda yüksek varyasyon göstermesi çeliklerin morfolojik özelliklerinin IBA dozları arasındaki interaksiyonun önemini ortaya koymaktadır. Araştırmada genel olarak kontrol gurubuna göre 500 ppm IBA dozunun canlılık oranını, 1000 ppm IBA dozunun köklenme oranını ve 1500 ppm IBA dozunun ise kök sayısı ve uzunluğunu daha çok etkilediği ortaya konulmuştur. Çeliklerin morfolojik karakterleri kendi aralarında değerlendirildiğinde canlılık oranı ve kök uzunluğu arasındaki istatistiksel bağın negatif yönde olduğu, kök oranı ve kök sayısının ise birbirine yakın interaksiyon gösterdiği görülmüştür.

PCA - Biplot

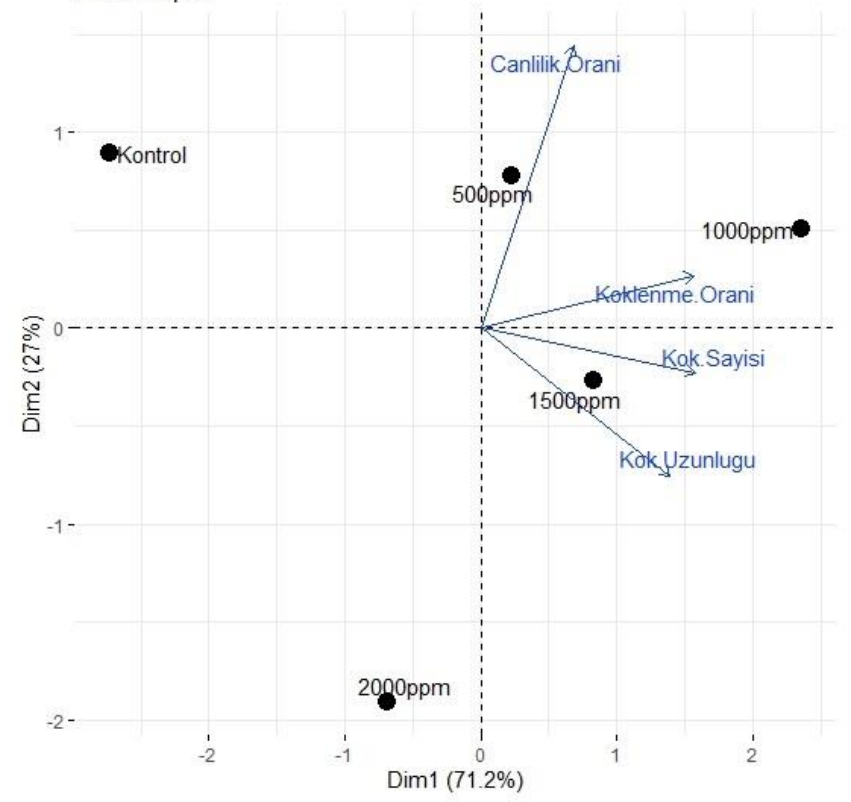

Şekil 2. IBA dozları ile çeliklerin köklenme performansları arasındaki korelasyon.

Figure 2. Correlation between IBA doses and rooting performance of blackberry cuttings.

Verilen bulgular neticesinde genel olarak elde edilen kök sayısı ve kök uzunluk verileri Korkut ve ark. (2017) 'Chester' böğürtlen çeşidinde yapmış oldukları çelikle çoğaltma çalışması verileriyle benzerlik göstermektedir. Nitekim 5 farklı köklendirme ortamı ve 3 farklı uygulamayı denedikleri çalışmalarında perlit ortamında 17.53 ile 23.20 adet arasında kök sayısı, 4.80 ile $11.40 \mathrm{~cm}$ arasında kök uzunluğu elde etmişlerdir. Kök sayısı bakımından en yüksek sonuçları 500 ppm IBA uygulamasından, en düşük sonuçları ise Bioone bakteri uygulamasından almışlardır. Bunun yanında Bobrowski ve ark. (1996), böğürtlenin odun çelikleriyle çoğalıımının basit olduğunu ancak köklenme oranının düşük $(<\% 50)$ olduğunu belirtmektedir. Araştırıııların bu bildiriminin aksine çalışmamızda 7-11 mm çapındaki odun çeliklere 1000 ppm IBA uygulaması yaparak \%80.0 köklenme sağlanmıştır.

Araştırma sonuçlarına göre IBA uygulamasının kontrol uygulamasına kıyasla çok daha iyi sonuçlar verdiğini görülmüş, incelenen tüm kriterlerde 1000 ppm dozun daha etkili olduğu tespit edilmiştir. Weaver (1972), oksin grubu büyümeyi düzenleyici maddelerden olan IBA'in saçak kök oluşumunu teşvik ettiğini belirtmektedir. Böğürtlen çeliklerine IBA uygulaması ile ilgi çeşitli çalışmalar yapılmış ve değişik sonuçlar alınmıştır (Zimmerman ve ark., 1980; Lopez-Medina ve Moore, 1997; Busby ve Himelrick, 1999; Bray ve ark., 2003). Lopez-Medina ve Moore (1997), 'Arkansas' böğürtlen çeşidi odun çeliklerine \%0.3 IBA uygulaması ile kök hacminin geliştiğini; Busby ve Himelrick (1999) 4 farkı böğürtlen çeşidi yarı odun çeliklerine IBA uygulaması ile (\%0.1, \%0.3 ve \%0.8 sıvı ve toz) çeliklerin kök sisteminin çok daha iyi geliştiğini; Bray ve ark. (2003), 3 farklı böğürtlen odun çeliklerine 0 ve 3000 ppm IBA uygulaması yapmışlar ve en yüksek sonuçları 3000 ppm IBA uygulamasından almışlardır. Bu araştırmaların yanında Maia ve Botelho (2008), IBA ve Paklobutrazol'un farklı dozlarının 'Xavante' böğürtlen çeliğinin köklenmesi üzerine yaptıkları araştırmada, paklobutrazol'un köklenme üzerine etkisinin olmadığı, 2000 ppm IBA dozunun en iyi köklenmeyi (\% 60) sağladığı, 1000 ppm'lik IBA dozunun da \% 56 köklenme sağladığı ve çelik başına 17.6 adet kök oluşturduğunu bulmuşlardır. Dias ve ark. (2011), böğürtlen çeliklerine 6 farklı IBA dozu $(0,250,500,1000,2000$ ve 4000 ppm) uygulamışlar ve en iyi köklenme oranlarını 250 ve 1000 ppm IBA uygulamasından almışlardır. Ayrıca çalışmamız neticesinde IBA'nın dozunun 0 ppm'den 1000 ppm'e doğru arttıkça sonuçların artış, 1000 ppm'den 2000 ppm'e doğru arttıkça sonuçların azalış gösterdiği belirlenmiştir. Nitekim yukarıda atıfı yapılan Maia ve Botelho (2008), 1000 ppm üzerindeki IBA dozlarının köklenme oranını 
azalttığı; Dias ve ark. (2011), 2000 ve 4000 ppm'lik IBA dozunun kök gelişimini engellediğini belirtmeleri bulgularımızı desteklemektedir.

Çalışma bulgularında çelik çapının köklenme ve kök kalitesi üzerine etkili olduğu bulunmuştur. Sürgünlerin orta kısmından alınan 7-11 mm çapındaki çelikler en yüksek sonuçları vermiş ve ideal çelik çapının sınırlarını bize göstermiştir. Bunun yanında sürgünlerin dip kısmından alınan çeliklerden ise en düşük sonuçlar alınmışır. Bulgularımıza paralel olarak Hartmann ve ark. (2011), çelik çapının yaprağını döken bitkilerde köklenme üzerine etkili olduğu ve bir yıllık sürgünlerin orta kısmından alınan çeliklerin tomurcuk gelişiminin iyi olması nedeniyle çok daha iyi köklendiği belirtmektedir. Bray ve ark. (2003), 'Apache', 'Arapaho', ve 'Navaho' böğürtlen çeşidi odun çeliklerinde çelik çapının köklenme oranı üzerine önemli etkiler oluşturduğunu belirtmekte ve sürgünlerin dip kısmından alınan çeliklerden en yüksek, uç kısmından alınan çeliklerden ise en düşük sonuçlar alındığını belirtmektedirler. Bulgularımız araştırıııların bildirimleriyle kısmen örtüşmektedir. Bunun yanında Tezel ve ark. (2016), hünnapta yapmış oldukları çalışmada, sürgünlerin orta kısmından alınan 5-7 mm çapındaki çeliklerin uç ve alt kısımdan alınan çeliklere kıyasla daha iyi köklendiğini belirterek bulgularımızı desteklemektedirler.

\section{SONUÇ}

Böğürtlen çok çeşitli değerlendirme şekli olmasından dolayı tarıma dayalı sanayi kuruluşları için ekonomik öneme sahip bir meyve türüdür. Bu sebeple dünyada olduğu gibi ülkemizde de böğürtlen yetiştiriciliğine talep yıldan yıla artmaktadır. Artan talebin karşılanabilmesi için her şeyden önce piyasada tutulan ve rağbet gören kaliteli böğürtlen fidanlarının yeterli sayıda üretilmesi gerekmektedir. Fidan üretiminde uygulanması basit, üretim maliyeti düşük ve çoğaltma katsayısı yüksek olan çelikle çoğaltma yöntemleri tercih edilmelidir.

Odun çelikleri ile çoğaltma ticari ve amatör fidan üretiminde yaygın olarak kullanılmamakla birlikte bu çoğaltma tekniği sayesinde işe yaramaz kış budama atıkları değerlendirilerek bitki başına çok sayıda fidan üretimi yapılabilmekte ve üreticiler için fidan maliyeti azalmaktadır.

Bu çalışmada 'Chester' dikensiz böğürtlen çeşidinin odun çelikleriyle çoğaltılmasında IBA (indol butirik asit) uygulamasının ve çelik çapının etkileri araştııımıştır. Araştırma sonuçları, dikensiz 'Chester' böğürtlen çeşidinin odun çelikleriyle çoğaltımının mümkün olduğunu göstermiştir. Çalışma sonucunda, IBA uygulamasının çeliklerin köklenmesi üzerine değişken etkileri olduğunu göstermiş ve en iyi sonuçlar 1000 ppm IBA uygulamasından alınmıştır. Bunun yanında çeliklerin köklenmesi üzerine çelik çapının önemli etkisi olmuş ve en yüksek sonuçlar 7-11 mm çapında hazırlanan çeliklerden alınmıştır.

\section{ÇIKAR ÇATIŞMASI}

Yazarlar arasında herhangi bir çıkar çatışması bulunmamaktadır.

\section{YAZAR KATKISI}

Makalenin konu dizaynı, yöntem ve yazımı H.Z. tarafından yapılmıştır. İstatistiksel analizler ve yorumlanması M.G. tarafından yapılmıştır.

\section{KAYNAKLAR}

Ağaoğlu, S. (1986). Üzümsü Meyveler. Ankara Üniversitesi Ziraat Fakültesi Yayınları, No: 984, Ankara.

Ahrens, P. (1991). Nursery Production of Virus-Free Planting Material. APS Press, St. Paul, Minn.

Barut, E. (2004). Dünya ve Türkiye'de üzümsü meyve yetiştiriciliği ve ticareti. Türk Tarım Dergisi, 156, 60-67.

Bobrowski, V. L., Paulo, M. F., \& Petters, J. A. (1996). Mikropropagation of blackberries (Rubus sp.) cultivars. Brasil de Agrociencia, 2, 17-20.

Bray, M.M., Rom, C. R., \& Clark, J. R. (2003). Propagation of thornless arkansas blackberries by hardwood cuttings. Food and Life Sciences, Discovery, 4(5), 9-13.

Busby A. L., \& Himelrick, D. V. (1999). Propagation of blackberries (Rubus sp.) by stem cuttings using various IBA formulation. Acta Horticulturae, 505, 327-332.

Caldwell, J.D. (1984). Blackberry propagation. HortScience, 19(2), 13-15.

Dias, J. P. T., Ono, O., \& Dodrigues, J. D. (2011). IBA and carbohydrates on rooting of shoot cuttings from root cuttings of Rubus spp. Revista Brasileira de Fruticultura, 33(1), 666-671. 
Göktaş, A. (2011). Ahududu ve Bögürtlen Yetiştiriciliği. Meyvecilik Araştırma Enstitüsü Müdürlüğü Yayınları, Yayın No: 38, Isparta

Hartmann, H. T., Kester, D. E., Davies, J. F. T., \& Geneve, R. L. (2011). Plant Propagation: Principles and Practices. Eighth Edition. Regents, Prentice Hall, New Jersey.

Korkut, E., Türemiş, N., Burğut, A., Büyükyel, Ş., \& Cömertpay, M. (2017). Chester Thornless böğürtlen çeşidinin çelikle çoğaltılması üzerine hormon ve bakteri uygulamalarının ve farklı topraksız kültür ortamlarının etkileri. Bahçe, 46(1), 311317.

Lopez-Medina, J., \& Moore, J. N. (1997). Propagation of erect blackberries by floricane stem cuttings. HortScience, $32(4), 602$.

Maia, A. J., \& Botelho, R. V. (2008). Plant regulators for rooting of hardwood cuttings of balckberry plants cv. Xavante. Semina: Ciências Agrárias, 29(2), 323-329.

Poling, E. B. (1996). Blackberries. Journal of Small Fruit \& Viticulture, 4(1-2), 33-69.

Takeda, F., Tworkoski, T., Finn, C. E., \& Boyd, C. C. (2011). Blackberry propagation by non-leafy floricane cuttings. HortTechnology, 21(2), 236-239.

Tezel, E., Kantar A., Aydın, E., \& Bostan, S. Z. (2016). Farklı IBA dozu ve çelik çapı uygulamalarının hünnap (Ziziphus jujuba Mill.) çeliklerinin köklenmesi üzerine etkisinin belirlenmesi. Bahçe, 45(1), 788-792.

The Comprehensive R Archive Network. (2020). https://cran.r-project.org/. Erişim tarihi: 26 Nisan 2020.

Thompson, E. (2004). Propagation of thornless blackberries utilizing adventitious shoots from root cuttings. Horticulture, 5 , 101-104.

TÜiK. (2019). Bitkisel üretim istatistikleri. https://biruni.tuik.gov.tr/medas/?kn=92\&locale=tr. Erişim tarihi: 10 Temmuz 2020.

Weaver, R.J. (1972). Plant Growth Substances in Agriculture. W.H. Freeman and Company, San Francisco.

Williams, M. W., \& Norton, R. A. (1959). Propagation of red raspberries from softwood cuttings. Proceedings of the American Society for Horticultural Science, 74, 1-406.

Zimmerman, R., Galletta, G. J., \& Broome, O. C. (1980). Propagation of thornlesss blackberries by one-node cuttings. Journal of the American Society for Horticultural Science, 105(4), 405-407. 